Relations industrielles

Industrial Relations

\title{
Sarapata, Adam, A Portrait of Bureaucracy. The Bankruptcy of the Socialist System in Poland
}

\section{Alexander J. Matejko}

Volume 48, numéro 1, 1993

URI : https://id.erudit.org/iderudit/050848ar

DOI : https://doi.org/10.7202/050848ar

Aller au sommaire du numéro

Éditeur(s)

Département des relations industrielles de l'Université Laval

ISSN

0034-379X (imprimé)

1703-8138 (numérique)

Découvrir la revue

Citer ce compte rendu

Matejko, A. J. (1993). Compte rendu de [Sarapata, Adam, A Portrait of Bureaucracy. The Bankruptcy of the Socialist System in Poland]. Relations industrielles / Industrial Relations, 48(1), 209-212.

https://doi.org/10.7202/050848ar

Tous droits réservés (C) Département des relations industrielles de l'Université Laval, 1993
Ce document est protégé par la loi sur le droit d'auteur. L'utilisation des services d'Érudit (y compris la reproduction) est assujettie à sa politique d'utilisation que vous pouvez consulter en ligne.

https://apropos.erudit.org/fr/usagers/politique-dutilisation/ 
Otherwise, she has succeeded in taking a rather limited cross-section of one small area of the rust belt and used it to raise broad questions about social solidarity and governmental responsibility that remain as yet unanswered.

Charles J. McCollester

Pennsylvania Center for the Study of Labor Relations, IUP

\section{A Portrait of Bureaucracy. The Bankruptcy of the Socialist System in Poland, by Adam Sarapata, Poznan, Delft, 1992, 227 p., ISBN 83-85308-07-5}

The disenchantment with the state socialist systems in eastern Europe had already been growing gradually much before the collapse of the Communist rule. The evidence of it in the Polish case is available much more than in other countries due to the developed sociological studies tolerated by the regime. Sarapata is a well known Polish sociologist in the field of work and management, and this book is a summary of his empirical studies done in the 1970s and the 1980s. According to J. Szczepanski in his introduction, (one of the most prominent contemporary Polish sociologists), this book "...explains, indirectly and directly, the perseverance of the stereotype of the relation between state and society as two opposing social entities, and also explains the perseverance of inclinations towards antagonistic actions ... The data contained in the book present the state of social consciousness and the strength of pressure exerted upon the decisions made by the authorities by the politically active masses." (p. 13).

It is worth adding that this high level of dissatisfaction has also continued under the postcommunist rule and from that perspective data collected by Sarapata illuminate the deep sources of socio-economic imbalance in Poland. The author demonstrates that undesirable attitudes towards work and the workplace are deeply rooted in poor working conditions, inadequate management, low level of democratization, and the more or less justified lack of confidence of subordinates in the professional and administrative competence of their supervisors. "The poor condition of Polish society and the dramatic situation of the country are closely linked to the faulty functioning of public administration, and the defects of the latter are bad omens for the future of both individuals and the country."' (p. 20)

Unfortunately, the depoliticization of the Polish economy (over $90 \%$ of bosses used to be either members of the Communist party or members of political bodies fully subordinated to the former), as well as progressing marketization and privatization, have so far not eliminated the roots of disenchantment, evidenced in the lack of genuine entrepreneurship, low administrative and managerial skills of the people in power at the local, regional or central levels, very low real incomes, and lack of a clear and convincing relationship between work and remuneration. While Sarapata relates these phenomena to the model of state socialism, there is also a continuation of old shortcomings under the new socio-economic order. In addition, the unemployment rate (13\% and growing) is a painful experience, especially for the young people who enter the labour market.

The first Chapter deals with aspirations, apprehensions and hopes of the Poles. According to 1984 data, Poles, especially unskilled workers, were much less happy than 
West Europeans, and this has probably not changed much since. Even the members of the ruling Communist party were not necessarily happier than the rest. Deprivations in housing, work and leisure were commonly shared, especially among the young and the occupants of lower positions. As Sarapata says, "In 1984 the situation of Poles resembled that 25 years earlier (it was only slightly better), and the crisis manifested itself not only in the low value of the mean and its strong decline, but also in considerably limited prospects for the future." (p. 56). Now there is great pessimism and the new elite which took power from the Communists has largely disillusioned the masses. Many Poles expected much more from the abolishment of Communism than what actually happened. The free market economy was supposed to lead to the miraculous improvement of the living standard but this became valid only for a few. The loss of the Eastern markets was a heavy blow for the Polish economy and the intensification of trade exchange with the West has so far not compensated this loss.

The second Chapter deals with the sources of collective misfortune as perceived by Poles still under Communism. These sources include laziness of people, low quality work, faulty organization, alcoholism, and lack of discipline. Again, there was no essential difference in opinions between the members of the ruling party and the rest, except that the former emphasized the importance of the passivity and indifference of society. There was a general demand to rationalize the economy and to democratize public life, and the emphasis on egalitarianism had actually declined instead of growing under socialist rule. Attitudes favoring a reduction in income differences were most common among unskilled workers, and least common among professionals; the hierarchy of what was perceived as fair earnings among Poles was similar to the Swedish public image. This partly explains the present dissatisfaction among many Poles with the growing polarization of the living standard. Under socialism there was also much inequality, but at least conspicuous consumption was restricted; now, those Poles who are well off publicly enjoy their privileged positions which, according to many, are undeserved.

Sarapata's third Chapter examines the place of work in the Polish value hierarchy. Work is valued quite highly, but is frustrated by the negative conditions representing one of the most evident failures of state socialism. Unfortunately, not much has improved in the postcommunist era. The basic conclusion of the author is that "The conditions depend primarily on the intellectual, moral, and managerial qualifications of those who decide about the principles and the system of the functioning of society." (p. 94). He blames the Communist administration for neglect. Data collected by the author indicate that private farmers, in several respects, appeared to be happier with their heavy work than public sector employees, especially unskilled blue collar workers, even when Polish private agriculture was greatly neglected by the state socialist rulers. Deprivations experienced by hired labour under state socialism were very common and they led to the negative evaluation of supervisors. It is also true that under the rigid bureaucracy, the managerial ranks had little to say and they were under constant pressure from the top to deliver as much as possible to fulfil quotas. A considerable part of remuneration at all levels consisted of bonuses for extraordinary performance (overfulfillment of production plans).

Sarapata devotes Chapters four and five to the social image of state bureaucracy and power. It is evident that scepticism and criticism of the socialist welfare state was 
already wide-spread in Poland before the collapse of the Communist power, especially in cities with populations exceeding 50,000 . The previous rulers managed to take care of only a small part of society, especially those sectors badly needed to maintain and defend the socialist order. The image of the rulers as neglecting vital social needs, promoting a protection system, disallowing most citizens to become active, according to their own will, mistreating clients who addressed authorities regarding their justified and urgent claims (such as housing), and making little effort to learn about the real human needs and conditions, was actually positive only in the privileged minority of the population and it deteriorated with the development of the Communist rule. As Sarapata says, "The overwhelming majority of the respondents feel alienated, and a large majority of them believe that the new authorities (those which imposed martial law and were carrying out an economic reform) enjoy less confidence than the authorities in power before 1980." (p. 102).

Nearly one-half of the respondents in the 1984 survey assessed the degree of the protective functions of the state as low or very low, especially the large sociooccupational groups (such as unskilled and semiskilled workers) in comparison with the privileged few at the top (the army and the ruling party cadres). In that respect there was an evident gap between two perspectives: from the top and from the bottom. The rulers were convinced that the protective functions of the welfare state became overextended and the average people became spoiled. On the other hand, the majority of the population criticized the authorities for the poor standard of living (much lower than in the developed free market societies), inefficient and corrupt administration, the "sweet life" of the privileged, and sycophancy versus the Soviet rulers.

It is worth mentioning that such a gap exists even now under the anticommunist leadership, not only due to the genuine ineffectiveness of the reforms but probably primarily due to the frustrated mass expectations regarding the advantages of the pro-West political and economic orientation. The previous common concerns with the bad financial situation, lack of attractions, insecure future, poor living conditions, low earnings and the uncertain national future, are being manifested even when Communism has disappeared from power. Before the collapse of state socialism, those Poles who were well off obviously had a more positive assessment of rulers than the rest of the population. The same tendency appears now, but the numbers of those feeling satisfied and having good reasons for being optimistic have not become large enough to guarantee the security of the socio-economic and political order. Under the Communist rule, it was tough enough to suppress public manifestations of dissatisfaction; under the new conditions, the industrial and political peace becomes continuously disrupted.

The tension between support and protest, activeness and passivity, is the concern of Chapter six. The depreciation of the law and its loss of prestige were related, under Communism, to the wrongdoing of the authorities and the arbitrary imposition on the Poles of a socio-political and economic system which they neither accepted nor enjoyed. The system of lodging complaints as a method of correcting possible faults was not popular among the rank-and-file, and is probably not any more popular now, even if free trade unions do exist and even compete with each other for popularity among their membership. 
Now, a few years after the abolishment of Communism, new tensions and protests appear in Poland. Workers in the state owned industrial enterprises strike and demonstrate for better wages, and the same happens with private farmers who used to enjoy heavy indirect or direct subsidies which are impossible to maintain within the new free market economy. Actually, the low gross domestic product of Poland (US $\$ 1,850$ per capita in 1991 compared with close to almost US $\$ 20,000$ in Germany, over US $\$ 3,000$ in Hungary and very little less in Czechoslovakia) does not allow any major growth of incomes as long as the economy remains stagnant. In Czechoslovakia and Hungary the average monthly income in 1991 was only $20 \%$ higher than in Poland when the latter had a much lower GDP per capita. The sick Communist economy has left a negative heritage, which manifests itself in low work morale, a poor sense of duty, and the tendency to make unjustified claims.

Unfortunately, the author of the book completely omits the vital issue of how much the present condition of Polish society is actually handicapped by the past. This is definitely a gap in a book dealing exclusively with the Communist past, without any reflection on the present.

The author has formulated several useful generalisations but unfortunately he does not provide an adequate evidence of how reliable they are statistically. There is, in addition, not enough recognition of other Polish data collectors who have also made valuable contributions arranging surveys. The conclusions offered in the book would benefit greatly from showing to what extent the data offered by the author actually agree or disagree with other contemporary survey testimonies. During the 1970 s and the $1980 \mathrm{~s}$ there were several more or less reliable (some data collecting was definitely biased politically) surveys of the Polish blue collar and white collar workers. The contribution made by Sarapata is a significant one, but definitely not the only one.

Alexander J. Matejko

University of Alberta

Index et résumés des sentences arbitrales de griefs, logiciel «NATUREL», Montréal, Coplanam Ltée, 1992.

Suite à la publication d'une recension sur le tome VII de l'ouvrage Index et résumés des sentences arbitrales de griefs (Relat. ind., vol. 47, ${ }^{\circ} 2,1992$, p. 380), l'éditeur nous informe qu'est dorénavant sans fondement notre remarque voulant qu'un « service informatisé » serait excessivement bienvenu. La maison Coplanam nous signale en effet que : "Conscients des efforts que pouvait représenter la consultation d'une telle masse d'informations, l'auteur et l'éditeur entreprenaient l'an dernier d'informatiser ces ouvrages. À l'aide du logiciel «NATUREL », l'ensemble de l'information des 5 dernières années a été traitée et est maintenant offerte sous la forme d'une banque informatisée, installée sur tout ordinateur personnel (compatible I.B.M.). Il ne s'agit pas ici d'un service offert par un serveur extérieur; l'information est inscrite sur le disque dur de l'appareil de l'usager et, par conséquent, il n'y a aucun frais d'utilisation. L'information peut être consultée n'importe où et à tout moment ". Nous nous excusons 